\title{
Polityka rosyjskiej Cerkwi prawosławnej wobec cudownych obrazów katolickiej proweniencji na wschodnich terenach dawnej Rzeczypospolitej w XIX w. na kilku przykładach
}

https://doi.org/10.26881/porta.2021.20.04

Słowa kluczowe: cudowne obrazy, sztuka religijna, Cerkiew prawosławna, Kościół katolicki, Kraj Północno-Zachodni, wschodnie tereny Rzeczypospolitej

Keywords: miraculous images, religious art, Orthodox Church, Catholic Church, Northwestern Krai, eastern territories of the Polish-Lithuanian Commonwealth

W wyniku zaborów znacząca część terenów należących do Rzeczypospolitej znalazła się w granicach Imperium Rosyjskiego, w którym Cerkiew prawosławna pozostawała w ścisłym związku z państwem i stanowiła jedno z narzędzi polityki we wszystkich warstwach społecznych. Wykorzystywano ją dla budowy świadomości rosyjskiej na terenach dołączonych do carskiej Rosji. Przynależność do Cerkwi utożsamiano z przynależnością etniczną i na tej podstawie oceniano prawomyślność w sprawach państwowych. Wyznawców prawosławia postrzegano jako przedstawicieli narodowości rosyjskiej, wspierających cara i państwo rosyjskie, katolików zaś jako Polaków marzących o odrodzeniu swego państwa i wrogów państwa rosyjskiego.

Jako że religia odgrywała istotną rolę w życiu społecznym, nawrócenie katolików i unitów na prawosławie uznawano za jedną z możliwości pozyskania zwolenników caratu i osłabienia idei odrodzenia państwa polskiego. Michaił Murawjow w notatce przedstawionej imperatorowi w dniu 14 maja 1864 r. wymieniał metody służące wzmacnianiu rosyjskich rządów w „Kraju Północno-Zachodnim” i przede wszystkim zalecał „wzmocnić i wywyższyć rosyjską narodowość i prawosławie, aby nie było najmniejszego powodu do strachu, że tereny te mogą kiedykolwiek stać się polskimi"'. Prawosławie stawało się zatem narzędziem politycznym²,

1 Из бумаг граба М.Н. Муравьева. С предисловием графа С.Д. Шеремета, Санкт-Петербург 1898, s. 38.

2 Zbigniew Opacki, Likwidacja Unii kościelnej na „Ziemiach zabranych” w 1839 roku [w:] Polska - Ukraina. 1000 lat sąsiedztwa, t. 2, Studia z dziejów chrześcijaństwa na pograniczu kulturowym i etnicznym, red. Stanisław Stępień, Przemyśl 1994, s. 123. 
Volha które wykorzystywano do wpływania na życie konkretnych osób i całego spoBarysenka łeczeństwa. Odwoływano się w ten sposób do praktyk związanych z przynależnością religijną miejscowego ludu wprowadzanych wkrótce po rozbiorach Rzeczypospolitej.

$\mathrm{Na}$ terenach dołączonych do Rosji zaczęto prowadzić politykę przekształcania cerkwi unickich na prawosławne. W wyniku likwidacji unii w $1839 \mathrm{r}$. oraz powstań z lat 1830-1831 i 1863-1864 w zachodnich guberniach Imperium Rosyjskiego do Cerkwi trafiła duża liczba świątyń chrześcijańskich obrządku zachodniego. W architekturze i wyglądzie wewnętrznym świątyń oraz ich wyposażeniu wprowadzono zmiany, aby nadać im charakter typowy dla tradycji prawosławnej ${ }^{3}$ Wraz z nieruchomościami w ręce Cerkwi trafiła duża liczba dzieł sztuki sakralnej o proweniencji zachodniochrześcijańskiej. Należało przyjąć określoną strategię polityczną, bowiem jednoczesne zastąpienie wszystkich wizerunków zachodnich ( $w$ tym rzeźb) ikonami malowanymi według tradycji prawosławnej nie było możliwe. Wykorzystanie zachodnich obrazów nie było zaś zgodne z zasadami prawosławia.

Wkrótce znaleziono rozwiązanie. W $1840 \mathrm{r}$. wydano rozporządzenie imperatora oraz Świętobliwego Synodu, by obrazy sakralne świętych, otoczone kultem w Cerkwi prawosławnej pozostały w cerkwiach, zaś obrazy świętych Kościoła katolickiego zostały oddane katolikom ${ }^{4}$. Dopuszczono także sprzedaż wizerunków sakralnych $\mathrm{z}$ cerkwi pounickich ${ }^{5}$. Natomiast obrazy pozostawione w cerkwi podlegały rozmaitym przekształceniom. Na przykład w $1846 \mathrm{r}$. generał-gubernator witebski, smoleński i mohylowski, książę Andriej M. Golicyn zwrócił uwagę na inskrypcje w języku polskim i łacińskim w cerkwiach prawosławnych, co doprowadziło do rozporządzenia, by zamienić je na cerkiewno-słowiańskie we wszystkich cerkwiach diecezji połockiej ${ }^{6}$. Umieszczanie napisów cerkiewno-słowiańskich na obrazach zachodnich odbywało się nie tylko na terenach diecezji połockiej, lecz także na terenach innych diecezji zachodnich guberni rosyjskich. Jednocześnie praktykowano przemalowywanie całych obrazów „na prawosławny ład” („на православный лад”). Tak było chociażby w przypadku ikonostasu z cerkwi Przemienienia Pańskiego w monasterze żyrowickim,

3 Warto zaznaczyć, że nie zawsze się to udawało w praktyce. W dużej liczbie cerkwi pounickich, przekształconych na prawosławne, nadal pozostawały dzieła sztuki sakralnej stworzone w tradycji malarstwa zachodniochrześcijańskiego, zatem rzeźby, obrazy w stylistyce zachodniej lub wizerunki świętych Kościoła katolickiego, zob. Николай Дмитриевич Извеков, Исторический очерк состояния Православной Церкви в Литовской епархии за время 1839-1889, Москва 1899, s. 389-393; Paweł Sygowski, Rosyjskie Muzeum Cerkiewno-Archeologiczne w Chetmie (1882-1915) - jego powstanie i zbiory sztuki religijnej (malarstwo, rzeźba), „Rocznik Chełmski” 2013, t. 17 , s. 87.

4 Państwowe Historyczne Archiwum Białorusi w Mińsku [НИАБ], ф. 136, оп. 1, д. 15518, f. $1-1 \mathrm{v}$.

Zob. НИАБ, ф. 136, оп. 1, д. 39453 о uzyskaniu pozwolenia na sprzedaż ikon pozostałych po unickiej cerkwi Objawienia Pańskiego w Łohojsku.

6 НИАБ, ф. 136, оп. 1, д. 192, f. 1-1v. 
którego odnowienie było równoznaczne z odsłonięciem osiemnastowiecznych kompozycji spod przemalowań dziewiętnastowiecznych?

Niektóre dzieła sztuki ze świątyń unickich lub katolickich trafiały w ręce osób prywatnych. W ten sposób w pałacu Chreptowiczów w Szczorsach znalazły się dwa obrazy pędzla Bacciarelliego, które wcześniej znajdowały się w miejscowej cerkwi. Po likwidacji unii duchowieństwo prawosławne walczyło o te wizerunki, uzasadniając, że na jednym obrazie przedstawiono Chrystusa Zbawcę, a na drugim Boga Ojca, co miało walor dydaktyczny dla prostych odbiorców wiejskich ${ }^{8}$. Do muzeum starożytności Tyszkiewiczów w Łohojsku trafiła cudowna ikona Matki Bożej w typie Znaku (Знамение) z miejscowego monasteru bazyliańskiego. Potem zbiory z muzeum w raz z ikoną nabył Henryk Tatur. Dopiero w 1907 r. trafiła ona do miejscowej cerkwi prawosławnej’.

Ponadto z kultu prawosławnego miały być wycofane wizerunki zachodnie, które znajdowały się w domach prywatnych. Sprzyjało temu poświęcanie domów przez duchownych na święta Bożego Narodzenia i Objawienia Pańskiego. Proponowano wówczas nowe papierowe wizerunki, drukowane na takie okazje w Moskwie, stanowiące kopie cudownych obrazów i przedstawiające rosyjskich świętych ${ }^{10}$.

Jedna grupa wizerunków pochodzenia zachodniochrześcijańskiego została przyjęta do kultu Cerkwi prawosławnej niemal bez zmian ikonograficznych oraz związanych z ich czcią tradycji ludowych. Były to otoczone kultem lokalnym lub powszechnym cudowne wizerunki Najświętszej Panny Marii, a w niektórych przypadkach również wizerunki Chrystusa. Wiązało się to z oddziaływaniem obrazów na miejscową społeczność: kult cudownych wizerunków miał charakter ponadwyznaniowy, chrześcijanie czcili je niezależnie od tego, w jakiej świątyni się znajdowały. Ingerencja w warstwę malarską takiego wizerunku mogła doprowadzić do konfrontacji z parafianami i utrudnić duszpasterstwo, co było niepożądane.

Ponadto w świątyniach prawosławnych znajdowało się o wiele mniej cudownych wizerunków i relikwii niż w kościołach katolickich. Fakt ten oraz działalność misyjna kleru katolickiego sprawiały, że chłopi uznawali katolicyzm za lepsze wyznanie niż prawosławie ${ }^{11}$. Sprowadzanie $\mathrm{z}$ kościołów katolickich do cerkwi cudownych wizerunków mogło, zdaniem władzy, sprzyjać szerzeniu prawosławia w miejscowościach zamieszkanych głównie przez katolików.

\footnotetext{
Беларускі іканастас. Творы іканапісуі драўлянай пластыкі канияа XVII-nач. XIX cm. Буклет да выстаўкі, склад Алена Карпенка, Мінск 2015, s. 15-22.

8 Галіна Аляксандраўна Флікоп-Світа, Барацьба за выяву Бога: лёс алтарных кариін иарквы у вёсцы Шиорсы Навагрудскага павета пасля скасавання Уніi, „Архіварыус” 2017, вып. 15, s. 295-296.

9 Епархиальная хроника, „Минские епархиальные ведомости” 1907, $\mathrm{nr}$ 18, s. 365.

10 Акт благочиннической конгрегации (собора) Брагинского благочиния, Минской губернии, Речицкого уезда, „Литовские епархиальные ведомости” 1864, nr 14, s. 515-516.

11 Михаил Долбилов, Русский край, чужая вера: этноконфессиональная политика империи в Литве и Белоруссии при Александре II, Москва 2010, s. 334.
} 
Aby uzasadnić funkcjonowanie takich wizerunków w Cerkwi prawosławnej, tworzono nowe legendy o pierwotnym prawosławnym pochodzeniu obrazów (a potem przemalowaniu ich przez katolików), a konfiskatę przedmiotów kultu z kościołów katolickich przedstawiano jako prawdę historyczną podeptaną przez polskie panowanie ${ }^{12}$. Ewentualnie podejmowano próby teologicznego uzasadnienia obecności obrazów w kulcie cerkiewnym, nawet w przypadkach, kiedy nadal pozostawały one w świątyniach katolickich, tak jak najbardziej czczone na terenach Rzeczypospolitej obraz Matki Bożej Częstochowskiej i obraz Matki Bożej Ostrobramskiej. Nieznany autor broszury o obrazie Najświętszej Panny Marii Częstochowskiej wskazał, że na terenach „dawnej Polski i Kraju Zachodniego Rosji” nie znano żadnej cudownej ikony w kościołach łacińskich, która nie byłaby dziedzictwem kościoła powszechnego albo nie byłaby zabrana z Cerkwi prawosławnej ${ }^{13}$. Autor doszedł do wniosku, że obraz Marii w klasztorze paulinów był dziedzictwem Cerkwi prawosławnej i trafił do katolików poprzez „przestępczy zabór" ${ }^{14}$. Podkreślił, że wersja o przybyciu obrazu z Bizancjum za pośrednictwem Karola Wielkiego (sic!) nie zasługuje na uwagę, natomiast za prawdopodobną uznał wersję o przyniesieniu jej z Konstantynopola na ziemie słowiańskie przez świętych braci Cyryla i Metodego ${ }^{15}$. Teza ta posłużyła jako argument, by w Częstochowie poświęcić cerkiew prawosławną pw. św. św. Cyryla i Metodego, wzniesioną w latach 1870-1872 ${ }^{16}$, gdzie umieszczono kopię cudownego obrazu jasnogórskiego.

Na przełomie XIX i XX w. prawosławne pochodzenie przypisywano również obrazowi Matki Bożej Ostrobramskiej, otoczonemu kultem powszechnym - pielgrzymowali do niego wierni różnych chrześcijańskich obrządków, najczęściej z terenów dawnego Wielkiego Księstwa Litewskiego. Obraz oparty na grafice niderlandzkiej w tradycji piśmiennictwa rosyjskiego miał być pochodzenia greckiego i był jakoby przywieziony do Wilna z Chersonezu (Korsunia) przez księcia Olgierda ${ }^{17}$, a trafił do karmelitów dopiero w XVII w. ${ }^{18}$

Ikonografię obrazu odnoszono do fragmentu Zwiastowania i twierdzono, że Archanioła Gabriela nierzadko malowano na oddzielnej desce ${ }^{19}$. Iwan

$12 \quad$ Ibidem, s. 339.

13 Ченстоховская чудотворная икона Богородицы в Ченстоховском Ясногорском монастыре и Церковь во имя святых равноапостольных просветителей славян Кирилла и Мебодия в городе Ченстохове с точною копией Ченстоховской святой иконы Богородицы, Вильна 1881, s. 6.

$14 \quad$ Ibidem, s. 7.

15 Ibidem, s. 11-12.

16 Ibidem, s. 32.

17 Иван Викентьевич Соболевский, Сказание об Остробрамской иконе Божией Матери, находящейся в Вильне, изд. 6-е, Вильна 1907, s. 11; Maria Kałamajska-Saeed, Ostra Brama w Wilnie, Warszawa 1990, s. 78.

18 Иван Викентьевич Соболевский, Сказание об Остробрамской иконе Божией Матери, находящейся в Вильне, s. 24.

19 Ibidem, s. 31. 
Sobolewski uznał, że twarz Marii została „ponowiona” w typie katolickich świętych dziewic w 1828 r., a na ikonie znajdował się napis cerkiewno-słowiański, przywołujący początek liturgii według św. Jana Złotoustego (Chryzostoma): Polityka rosyjskiej Cerkwi... „Честнейшую херувим и славнейшую без сравнения серафим” („Czcigodniejszą od Cherubinów i bez porównania chwalebniejszą od Serafinów”). Wersje o napisach w języku greckim lub cerkiewno-słowiańskim pojawiały się u różnych autorów rosyjskojęzycznych i dopiero podczas konserwacji obrazu w $1927 \mathrm{r}$. szczegółowe oględziny pozwoliły stwierdzić, że napisów na nim nie było ${ }^{20}$. Tym niemniej obraz Matki Bożej Ostrobramskiej przyjęto do kultu Cerkwi prawosławnej i w XIX w. do świątyń na terenach współczesnej Białorusi trafiło sporo jej kopii, które pozostają w kulcie do dzisiaj, a niektóre, takie jak obrazy Matki Bożej Ostrobramskiej w Iwieńcu i Słucku, otoczone są kultem lokalnym.

Warto zaznaczyć, że od lat sześćdziesiątych XIX w. nie wymagano nawet potwierdzenia domniemanej unickiej przeszłości cudownych wizerunków kościelnych, które mogły trafić do kultu prawosławnego. Uzasadnienie to nie było szczególnie trudne w przypadku mało znanych obrazów otoczonych kultem lokalnym. W taki właśnie sposób trafiały do Cerkwi prawosławnej obrazy z mniej znanych kościołów katolickich. W kościele w miasteczku Wierchowicze znajdował się cudowny wizerunek Matki Bożejej. W dzień przekazania obrazu w 1866 r. około osiemdziesięciu najstarszych parafian zaświadczyło, że obraz Najświętszej Panny Marii razem z dzwonami został przeniesiony w $1818 \mathrm{r}$. do kościoła z cerkwi unickiej pw. św. Mikołaja. Parafianie obiecali też potwierdzić swoje słowa pod przysięgą. W relacji z wizytacji w 1759 r. wskazanej cerkwi unickiej brakuje wzmianek o cudownym obrazie Matki Bożej, ale w szczególny sposób opisano cudowny wizerunek św. Mikołaja, który w XIX w. został przeniesiony do cerkwi prawosławnej ${ }^{22}$. Obraz od początku miał prawdopodobnie charakter katolicki (wspomniał o nim Jan Fryderyk Sapieha w książce Monumenta..., wydanej w $1721 \mathrm{r}^{23}$ ), lecz mimo to obraz pozostał w cerkwi prawosławnej ${ }^{24}$. Niestety, spłonął w pożarze świątyni podczas drugiej wojny światowej, trudno zatem powiedzieć cokolwiek o jego ikonografii.

W podobny sposób trafił do cerkwi prawosławnej w Zelwie w $1866 \mathrm{r}$. obraz Matki Bożej nazywanej Koniańską, który miał pochodzić z cerkwi unickiej

$20 \quad$ Kałamajska-Saeed, Ostra Brama $w$ Wilnie..., s. 78-79.

21 Waclaw z Sułgostowa (Nowakowski), O cudownych obrazach w Polsce Przenajświętszej Matki Bożej, Kraków, 1902, s. 718.

22 Litewskie Państwowe Archiwum Historyczne (Lietuvos valstybės istorijos archyve - LVIA), f. 634 , ap. 1, b. 48 , c. $268-271$.

${ }^{23}$ Jan Fryderyk Sapieha, Monumenta Antiquitatum Marianum Jn [sic!] Imagine Vetustissima, vulgo Gregoriana, a S. Augustino Romano depicta Jntegerrimee Virginis Deiparce de Gvadelupe Codnensis, Agusta Origine, [et] devoto Cultu Fidelium Gloriosissimo Laureatis Martyrum, Variorumq[ue] Coelitum; Exuvijs Circumdato, pars 1, Warszawa 1721, s. 130.

24 Освящение Верховицкого римско-католического костела в православную иерковь 1867 г 24 июля, и историческая заметка по поводу этого торжества, „Литовские епархиальные ведомости" 1867, nr 23, s. 1029-1031. 


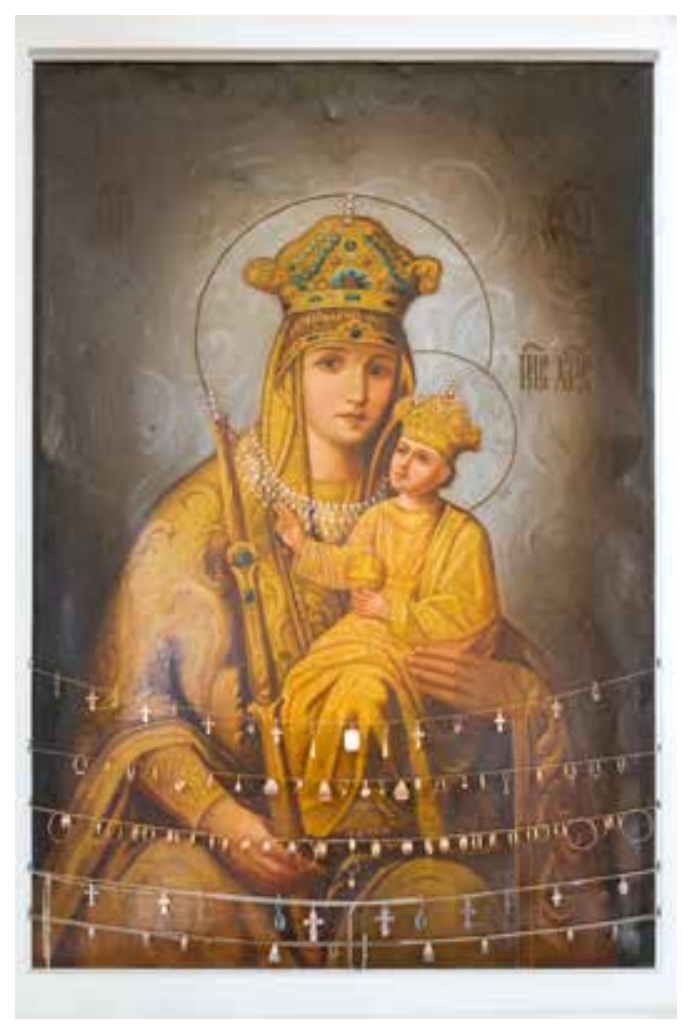

Il. 1. Ikona Matki Bożej Białynickiej, kopia cudownego obrazu z początku XX w., cerkiew w Białyniczach, fot. Włodzimier Sutiagin, 2012 we wsi Konno ${ }^{25}$. Wizerunek nie zachował się, nie wiadomo więc nic o jego ikonografii. W 1866 r. urzędnik ziemski (tzw. мировой посредник) P.M. Szczerba (Szczerbow) wysłał ikonę do Petersburga do malarza Górskiego (zapewne Franciszka Górskiego, zatrudnionego jako konserwator malarstwa w Ermitażu) z prośbą o wykonanie jej powtórzenia („с просьбой перенести изображение на другое полотно”) ${ }^{26}$. Kopię sprowadzono do Zelwy w 1866 r. ${ }^{27}$, jednak późniejsze losy kopii i oryginału są nieznane.

Bardziej skomplikowane było uzasadnienie przekazania Cerkwi prawosławnej cudownych obrazów maryjnych o rozpowszechnionym w Kościele katolickim kulcie. Najbardziej znanymi przykładami są obrazy Matki Bożej Białynickiej (il. 1) i Jurowickiej (il. 2), które zostały przekazane wraz z kościołami. W przypadku obrazu z Białynicz podejmowano najpierw próby ustalenia danych dokumentalnych o jego prawosławnym pochodzeniu. To się jednak nie udało, nie znaleziono żadnych dokumentów potwierdzających prawosławną proweniencję obrazu, mimo że lokalna legenda głosiła, iż obraz znajdował się pierwotnie w cerkwi. Podjęto więc decyzję o przekazaniu obrazu, uzasadniając, że ma on szczególne znaczenie dla wiernych ${ }^{28}$. W obrazie

25 Август Куцевич, Крестный ход из. Волковыска в м. Зельву с перенесением иконь Иверской Божией Матери, „Литовские епархиальные ведомости” 1867, nr 21, s. 887-894.

26 Ibidem, s. 887-900.

27 Куцевич, Крестный ход из. Волковыска в м. Зельву с перенесением иконы Иверской Божией Матери..., s. 887-894.

28 Василий (Жудро), Исторические материаль из дел Могилевской духовной консистории о передаче в православное духовное ведомство Белыничского римско-католического костела с находящеюся в нем чудотворной иконой Божией Матери Бельничский Рождество-Богородиикий монастьрь: В 2 ч. Кн. 2-3, б.в.д., s. 36-38; Aleksander Jaroszewicz, Przebudowy kościołów katolickich na cerkwie prawosławne na Białorusi po powstaniu styczniowym (w świetle materiałów archiwalnych) [w:] Kultura i polityka. Wpływ polityki rusyfikacyjnej na kulturę zachodnich rubieży Imperium Rosyjskiego (1772-1915), red. Dariusz Konstantynów, Piotr Paszkiewicz, Warszawa 1994, s. 150. 


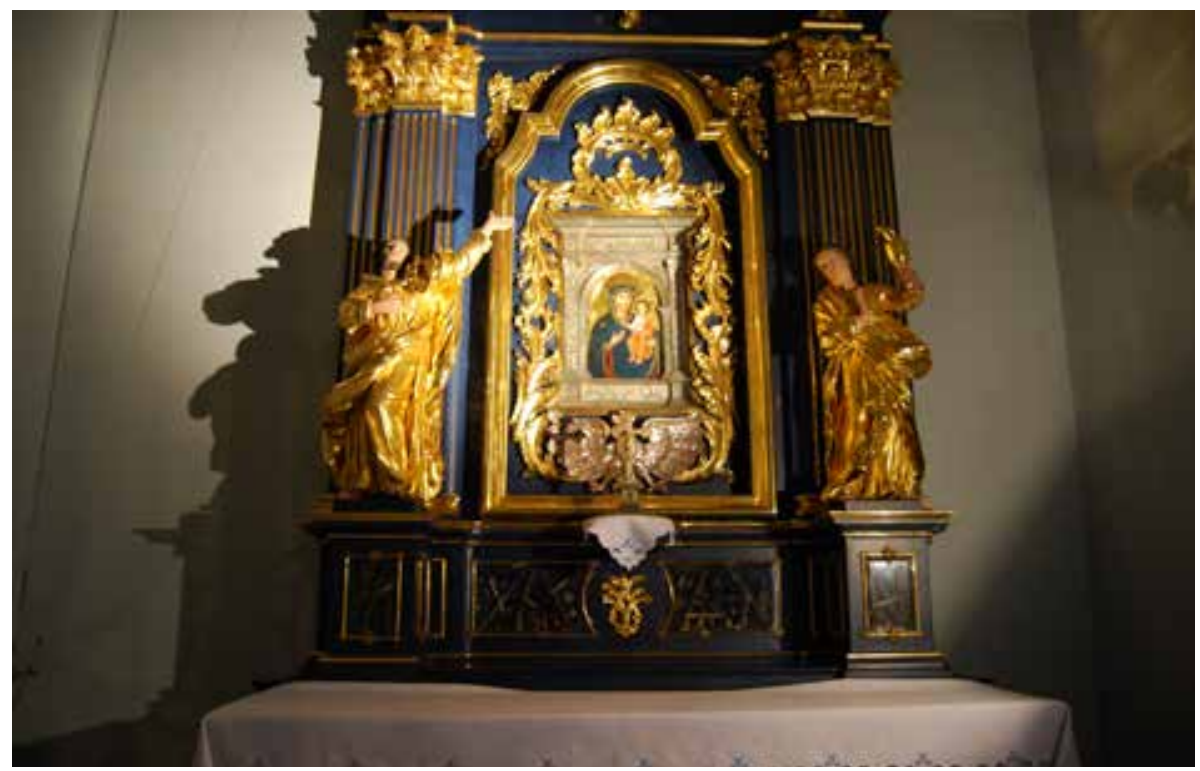

Polityka

rosyjskiej

Cerkwi...

Il. 2. Obraz Matki Bożej Jurowickiej, kościół św. Barbary w Krakowie, fot. Volha Barysenka, 2012

widziano bowiem główny fundament katolicyzmu w Białyniczach ${ }^{29}$. Budynek pokościelny poświęcono na cerkiew prawosławną w 1876 r. Pierwszą legendę o „prawosławnym pochodzeniu” obrazu Matki Bożej Białynickiej, tj. o jego przeniesieniu w XIII w. do Białynicz z Kijowa, opublikowano dopiero pod koniec XIX w. ${ }^{30}$ wraz z alternatywną wersją o pochodzeniu ikony z prawosławnego monasteru w Orszy, skąd miała być ukradziona przez katolików ${ }^{31}$. Wbrew temu, że na stronach wydań cerkiewnych końca XIX i początku XX w. wspominano legendę o namalowaniu ikony przez anioła w klasztorze karmelitańskim po fundacji klasztoru przez Lwa Sapiehę w 1624 r., to właśnie podanie o przeniesieniu ikony z Kijowa funkcjonuje dzisiaj w środowisku prawosławnym. Powtarza się w literaturze religijnej i naukowej ${ }^{32}$ oraz jest odzwierciedlona w nabożeństwie prawosławnym - w ikonie białynickiej Akafista do Matki Bożej33.

29 Jaroszewicz, Przebudowy kościołów katolickich na cerkwie prawosławne na Białorusi po powstaniu styczniowym ( $w$ świetle materiałów archiwalnych)..., s. 151.

30 Жудро, Белььничский Рождество-Богородицкий монастьрь..., s. 6, 34.

31 А.В.Б., Икона Бельничской Божией Матери... [w:] Виленский календарь на 1887 год, Вильна, 1886, s.107; Wiadomość historyczna o cudownym obrazie N. Panny Maryi w Białyniczach [w:] Posłaniec Bractwa N.P. Maryi Królowej Korony Polskiej, Kraków 1899, s. 14-15.

32 Zob. Dariusz Ciołka, Latynizacja Kościoła unickiego w Rzeczypospolitej po synodzie zamojskim, Białystok 2014, s. 58.

33 Ikos 2, ikos 3, zob. http://mogeparhia.by/svyatyni/икона-божией-матери-белыничская/ [dostęp: 18.06.2021]. 

sławnej wraz budynkiem kościelnym w $1864 \mathrm{r} .{ }^{34}$ Obrazowi jurowickiemu, podobnie jaki innym obrazom kościelnym, przypisano pochodzenie prawosławne - „zgodnie z miejscowym podaniem kościół zbudowali jezuici na miejscu prawosławnej cerkwi, z której pochodzi cudowny obraz" ${ }^{35}$. Chociaż oryginalny obraz został zamieniony na kopię przez księdza Hugo Gadzieckiego ${ }^{36}$, zarówno duchowieństwo prawosławne, jak i wierni byli przekonani, że w cerkwi znajduje się oryginał, a nie kopia. W dokumentach o przekazaniu kościoła podano, że kilkaset osób wyznania katolickiego wyraziło chęć nawrócenia na prawosławie w związku z obecnością cudownej ikony w cerkwi ${ }^{37}$. Jednak przeszkodą była działalność misyjna księdza katolickiego, który wielokrotnie ogłaszał, że prawdziwy obraz Matki Bożej Jurowickiej znajduje się w kościele i właśnie tam czyni cuda. W wyniku jego działalności katolicy, którzy początkowo chcieli nawrócić się na prawosławie, rezygnowali z tego zamiaru („упорно отказались”, dosł. uparcie odmawiali ${ }^{38}$.

W ręce Cerkwi trafił również obraz Matki Bożej Różanostockiej autorstwa - według Gabriela Jurkowskiego - grodzieńskiego malarza Jana Szrettera, który przed namalowaniem obrazu Bogurodzicy nawrócił się z luteranizmu na katolicyzm ${ }^{39}$. W artykule dotyczącym poświęcenia byłego kościoła na cerkiew w 1868 r. Sidor Jelenow stwierdził, że obraz jest pochodzenia prawosławnego i oskarżył księży o wymyślenie tej legendy („но едва ли эта легенда не умышленно сочинена польскими ксендзами" ${ }^{40}$ ). Uważał, że wizerunek Matki Bożej Różanostockiej był „wielkoruskim polowym obrazem". O jego prawosławnym pochodzeniu miało świadczyć malarstwo greckie, nieznane w Kościele rzymskim („Живопись совершенно греческая, не виданная в римской церкви")

W roku 1901 ukazała się broszura autorstwa duchownego Nikołaja Siemieniaki, który podjął próbę uzasadnienia prawosławnego pochodzenia obrazu różanostockiego. Duchowny twierdził, że istniały oryginał obrazu i jego kopia. Oryginał miał być pochodzenia ruskiego i stanowić własność książąt Urusowów,

34 НИАБ, ф. 136, оп. 1, д. 31071, f. 1.

35 Jaroszewicz, Przebudowy kościołów katolickich na cerkwie prawosławne na Białorusi po powstaniu styczniowym ( $w$ świetle materiałów archiwalnych)..., s. 147.

36 Сказание об истории и чудесах чудотворной иконы Божией Матери Юровичской Милосердной, Мозырь 2010, s. 14-16.

37 НИАБ, ф. 136, оп. 1, д. 31071, f. 18

38 Ibidem, f. $18 \mathrm{v}$.

39 Gabryel Jurkowski, Morze litości y łaski Bożey przepaściste z Rożanego-Stoku wylane..., Wilno 1762, b.p., zob. rozdział Oryginat albo samo opisani ziawienia Cudownego Obrazu Przenayświętszez MARYI Panny Rożano-Stockiej wespoł z Cudami, które się przy tym działy ziawieniu, Roku 1652.

40 Сидор Еленов, Освящение церквей: Освящение Красностокской церкви, „Литовские епархиальные ведомости" 1867, nr 22, s. 952.

41 Ibidem. 
po których w linii żeńskiej trafił do Eufrozyny Tyszkiewiczowej. W jej domu zasłynął cudami. Feliks Tyszkiewicz, mąż Eufrozyny, zabierał obraz na wyprawy wojenne. Aby Rożany Stok nie został bez cudownego wizerunku, Eufrozyna Polityka rosyjskiej Cerkwi... Tyszkiewiczowa zamówiła kopię u malarza-protestanta z Grodna. Namalował on kilka kopii na płótnie (oryginał miał być namalowany na desce cyprysowej), ale żadna $\mathrm{z}$ nich nie była udana, ponieważ na oryginalnym obrazie werniks był już pociemniały. Eufrozyna wybrała jedną z nich i umieściła w cerkwi różanostockiej ${ }^{42}$.

Pochodzenie prawosławne przypisywano też wizerunkowi Matki Bożej Boruńskiej z cerkwi monasteru bazylianów w Borunach. Obraz należał do bazylianina Jozafata Brażyca. W 1666 r. zasłynął cudami. W 1907 r., już po przekazaniu monasteru prawosławnym, ksiądz Michaił Paszkiewicz stwierdził, że obraz ma prawosławną proweniencję, a sposób, w jaki został namalowany, ujawnia jego „charakter bizantyjski, staroruski” („характера византийского, письма древне-русского" ${ }^{43}$. Wskazując analogie między wizerunkiem Matki Bożej Boruńskiej a ikonami Matki Bożej Kołożskiej i Supraskiej, „podarowanymi przez księżną Heleną", żonę króla Aleksandra ${ }^{44}$, duchowny sformułował wniosek, że obraz został namalowany przez malarzy moskiewskich lub lokalnych w czasach królowej Heleny dla Cerkwi prawosławnej, a został zabrany przez unitów, kiedy był już czczony jako cudowny, w celu propagowania unii i katolicyzmu ${ }^{45}$.

Ikona ta różni się kompozycyjnie od wzmiankowanych przez Paszkiewicza ikon Hodegetrii Wileńskiej i Kołożskiej. Trudno powiedzieć cokolwiek pewnego o powstaniu tego obrazu. Istnieje wersja, że oryginał zamieniono na kopię w XIX w. i ukryto przed prawosławnymi. Jednak w tym czasie ikonę zaadaptowano już do prawosławnych praktyk liturgicznych i opublikowano wiadomości o uczynionych przez nią cudach ${ }^{46}$.

Pochodzenie przynajmniej sześciu wizerunków maryjnych, znajdujących się wcześniej w świątyniach unickich i katolickich w okolicach Pińska, przypisywano

42 Николай Семеняко, Красностокская чудотворная икона Божией Матери, Гродно 1901, s. 3-8.

43 Михаил Михайлович Пашкевич, Чудотворная икона Богородицы в Борунах. С краткими сведениями о монастыре и училище, Вильна 1907, s. 15.

44 W historiografii ikony Matki Bożej Kołożskiej nie zapisano jednak legendy o jej podarowaniu do cerkwi przez królową Helenę. Według legendy, podanej przez Ignacego Kulczyńskiego w 1738 r. (Археограбический сборник документов, относящиися к истории Северо-Западной Руси, издаваемый при Управлении Виленского учебного округа, t. 9, Вильна 1870, s. 411-412) i powtarzanej w dziewiętnastowiecznej literaturze prawosławnej, ikonę nosił przy sobie starzec, który niedługo przed śmiercią przekazał ją do cerkwi boryso-glebskiej na Kołoży. Opisano ją jako namalowaną w stylistyce podobnej do ikony Hodegetrii Wileńskiej, zob. Помпей Николаевич Батюшков, Белоруссия и Литва. Исторические судьбы Северо-Западного края, Минск 2004 (переиздание), s. 174.

45 Михаил Михайлович Пашкевич, Чудотворная икона Богородищы в Борунах. С краткими сведениями о монастыре и училище, Вильна 1907, s. 16-17.

46 Ibidem, 18-19. 
Volha w latach sześćdziesiątych XIX w. prawosławnemu świętemu - Dymitrowi RostowBarysenka skiemu. Znalazł się wśród nich cudowny obraz Matki Bożej Ochowskiej, której kult, wspierany przez franciszkanów pińskich, rozwinął się w ośrodku unickim w XVII w. Według legendy obraz został podarowany Cerkwi przez św. Dymitra ${ }^{47}$.

Podobna legenda - z przełomu XIX i XX w. - towarzyszy obrazowi Matki Bożej Śnieżnej (il. 3), pochodzącemu z kościoła podominikańskiego w Stołpcach, oddanego prawosławnym w $1868 \mathrm{r}$. razem z czterema wizerunkami czczonymi w kulcie

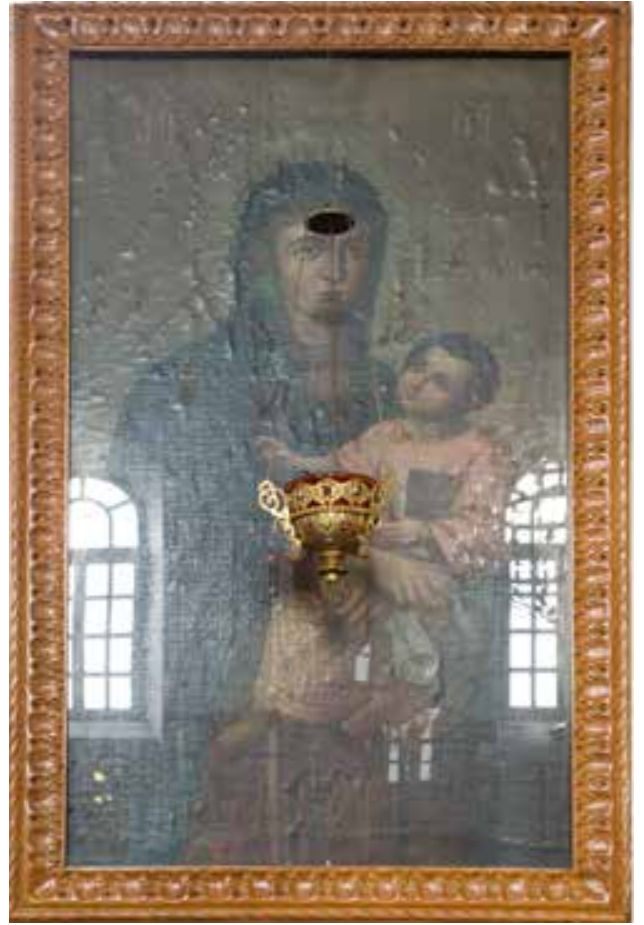

Il. 3. Obraz Matki Bożej Śnieżnej, cerkiew w Stołpcach, fot. Włodzimier Sutiagin, 2012 lokalnym: Matki Bożej, Michała Archanioła i feretronu dwustronnego $\mathrm{z}$ przedstawieniami Chrystusa i Matki Bożej. Pozostałe dobra oddano duchowieństwu katolickie$\mathrm{mu}^{48}$. Wiadomo, że kult obrazów Matki Boskiej i Marii Magdaleny w kościele przekształconym na cerkiew poświęconą Marii Magdalenie trwał do pierwszych dziesięcioleci XX w. Ikony przybywali oglądać zarówno wyznawcy prawosławia, jak i katolicy ${ }^{49}$.

Spośród czterech wspomnianych wizerunków udaje się dobrze prześledzić historię obrazu Matki Bożej w typie Salus Populi Romani, określanej również jako Śnieżna, datowanego na koniec XVIII lub początek XIX w. ${ }^{50}$ Ikonę Matki Bożej wielokrotnie przenoszono między świątyniami prawosławnymi i katolickimi w latach dwudziestych XX w. Najpierw, po rewindykacji budynku przez katolików, ikonę umieszczono w prawosławnej cerkwi św. Anny. Stamtąd zabrali ją katolicy, jednak w 1926 r. miejscowy ksiądz Zienkiewicz zwrócił obraz prawosławnym, uznając, że nie ma w nim nic katolickiego ${ }^{51}$. Obraz nadal znajduje się w cerkwi prawosławnej św. Anny w Stołpcach. Istnieje legenda, zapisana przed drugą wojną światową, że ikona została podarowana miejscowej cerkwi przez

47 Иоанн Проволович, Из путешествия Его Преосвященства, Преосвященнейшего Александра, епископа Минского и Бобруйского, по Епархии в 1873 году, „Минские епархиальные ведомости" 1873, nr 24, s. 567.

48 НИАБ, ф. 136, оп. 1, д. 32139, f. 12v.

49 Описание иерквей и приходов Минской епархии, составленное по официально затребованным от причтов сведениям. Ч. I: Минский уезд (Приложение к Минским епархиальным ведомостям за 1878 г.), Минск 1878, s. 162.

50 Аляксандр Адамавіч Ярашэвіч, Маці Божая Снежная ў Беларусі, Мінск 2003, s. 36.

51 Феодор Кривонос, Свято-Аннинская церковь в Столбиах, „Минские епархиальные ведомости" 2004, nr 3, s. 61. 
świętego Dymitra Rostowskiego ${ }^{52}$. Obecnie ikona nie cieszy się odrębnym kultem i nie wyróżnia się szczególną czcią w porównaniu z innymi ikonami cerkiewnymi.

Podane przykłady łączy wyobrażenie Matki Bożej w dopuszczanym w Cerkwi prawosławnym przedstawieniu Matki Bożej z Dzieciątkiem w typie Hodegetrii lub do niego zbliżonym. W tym przypadku łatwo było przytoczyć legendę o prawosławnym pochodzeniu ikony, dodać inskrypcje, jeśli były potrzebne, i wprowadzić do kultu cerkiewnego.

Ciekawym przykładem są obrazy otoczone kultem, co najmniej lokalnym, na których przedstawiono wizerunki zgodne z zasadami teologicznymi Kościoła katolickiego. Najczęściej są to obrazy Najświętszej Panny Marii, której kult w Rzeczypospolitej miał charakter ponadwyznaniowy - łączył prawosławnych, katolików i unitów. Apoteozą Matki Bożej, Unii Kościelnej i dawnej Rzeczpospolitej Mirosław P. Kruk nazwał ikonę Bramy Niebios, na której przedstawiono w centrum Matkę Bożą w typie zbliżonym do Wniebowzięcia Marii z Bogiem Ojcem, Chrystusem i Duchem Świętym pod postacią gołębicy. Pole środkowe otaczają święci Kościoła powszechnego - katolickiego, unickiego oraz prawosławnego. Przedstawienie Marii nawiązuje do ikonografii zachodniej, znanej jako Madonna Apokaliptyczna ${ }^{53}$.

Ikonografie zachodnie Koronacji Marii, Wniebowzięcia Marii, Niepokalanego Poczęcia i Madonny Apokaliptycznej trafiały do Cerkwi unickiej za sprawą Kościoła katolickiego i rozpowszechniły się w XVIII w. Wizerunki te nie były akceptowane przez Cerkiew prawosławną w carskiej Rosji, aprobowano je jedynie w przypadku, kiedy były czczone jako cudowne. Kilka z nich przetrwało do dzisiaj w cerkwiach prawosławnych na Białorusi, np. wizerunki Matki Bożej Tonowo-Słobodzkiej czy Krzywickiej.

Nazwa obrazu: Matka Boża Tonowo-Słobodzka (il. 4), pochodzi od dwóch wiosek - Tonowo i Słobodka w rejonie stołpcowskim obwodu mińskiego, między którymi wzniesiono cerkiew unicką, a potem prawosławną. Ikona znajduje się w cerkwi, można było ją zbadać wyłącznie wizualnie. Namalowano ją na płótnie naklejonym na deskę. W niektórych miejscach widoczne są znaczące ubytki warstwy malarskiej. Tło dookoła Matki Bożej i Dzieciątka zostało przemalowane. Jednak twarze, ręce i stopy Marii i Jezusa pozostały nienaruszone,

$52 \quad$ Ibidem. Warto zaznaczyć, że od lat siedemdziesiątych XIX w. w literaturze cerkiewnej częste były wzmianki o tym, że ten czy inny obraz na Białorusi, na ogół Matki Bożej otoczony kultem lokalnym, był ofiarowany do cerkwi przez św. Dymitra. Poświęcono temu artykuł oddany do druku, zob. Ольга Владимировна Борисенко, Белорусские чудотворные иконы Богоматери, связанные со святым Дмитрием Ростовским (Туптало) [w:] Волинська ікона: дослідження та реставрація. Науковий збірник. Випуск 28. Матеріали XXVIII міжнародної наукової конференції, м. Луцььк, 21-22 жовтня 2021 року. Упоряд. Т. Єлісєєва, Є. Ковальчук, Луцьк 2021, s. 52-61.

53 Mirosław Piotr Kruk, Złoty Ołtarz wonnego kadzenia albo ikona Bramy Niebios (?) w otoczeniu świętych trzech obrzadków - apoteoza Matki Bożej, apoteoza Unii kościelnej, apoteoza dawnej Rzeczypospolitej [w:] Sztuka cerkiewna Rzeczypospolitej i krajów sasiednich. Materiały dyskusyjne, red. Dominika Maria Macios, Magdalena Anna Piecyk, Maria Tsymbalista, Ostrawa-Warszawa 2020, s. $120-121$. 


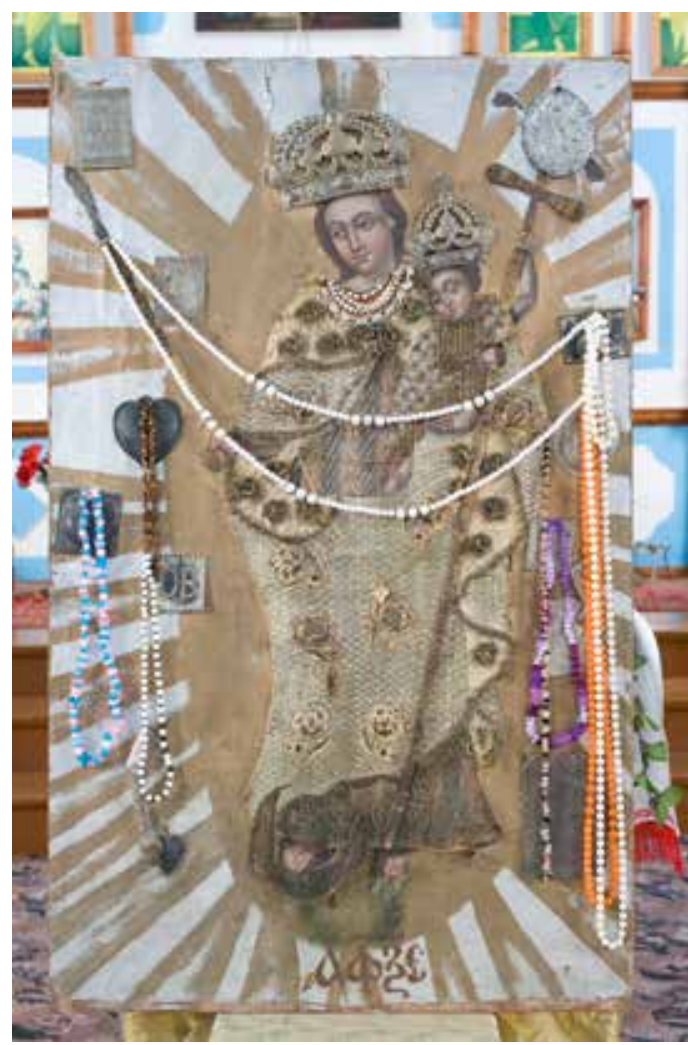

Il. 4. Ikona Matki Bożej Tonowo-Słobodzkiej, cerkiew w Słobodce, fot. Włodzimier Sutiagin, 2012 podobnie jak haftowana szata okrywająca obie postacie.

Matkę Bożą ukazano w charakterystycznej pozie - $\mathrm{z}$ Jezusem na lewym ramieniu i berłem w prawej dłoni. Przedstawiono ją bez maforionu, jej ciemne włosy opadają na plecy. Prawa stopa opiera się na półksiężycu. W pierwotnym wizerunku Maria lewą nogą deptała prawdopodobnie smoka - wskazuje na to poza Jezusa, który obydwoma rękami trzyma krzyż: z pewnością uderzał nim smoka znajdującego się obok stopy matki. Ten fragment obrazu został zamalowany, ale na postawie typu ikonograficznego i podobnych wizerunków można przyjąć, że smok rzeczywiście znajdował się na przedstawieniu. Spojrzenie Dzieciątka jest skierowane $\mathrm{w}$ miejsce, $\mathrm{w}$ które uderza krzyżem, Maria zaś patrzy nieco w dół i w stronę przeciwną. Kompozycja obu postaci, wraz z zamalowanym tłem, nawiązuje do kompozycji Madonny Apokaliptycznej ${ }^{54}$.

Ikonografia Dzieciątka odwołuje się do jego przedstawienia przez Carlo Marattę w dziele Maria Immacolata z kościoła Sant'Isidoro a Capo le Case w Rzymie oraz graficznych powtórzeń tego obrazu, a jednocześnie ma cechy wspólne z podobnymi przedstawieniami Matki Boskiej i Jezusa na obrazach i rzeźbach pochodzących z Polski. Typ ikonograficzny Madonny Apokaliptycznej jest obecny w rosyjskim malarstwie prawosławnym. Został adaptowany z Zachodu i znany jest jako typ Pocieszenie wszystkich strapionych (Всех Скорбящих Радость). Ikonografia obrazu z Tonowej Słobody dość znacząco różni się od namalowanych w tym typie ikon prawosławnych, pochodzących z terenów rosyjskich.

Kolorystyka twarzy oraz rąk pozwala datować ikonę na wiek XVII-XVIII, lecz ostateczne rozstrzygnięcie tej kwestii wymaga podjęcia badań laboratoryjnych połączonych z konserwacją obrazu. Postacie Marii i Dzieciątka są ukryte pod haftowanymi szatami - dekorowanymi kwiatami u Marii i czerwonymi

54 Aleksandr A. Jaroszewicz identyfikował ikonę jako odnoszoną do typu Niepokalanego Poczęcia. Typy te są bliskie sobie i nie zawsze da się je rozróżnić, zob. Аляксандр Адамавіч Ярашэвіч, Царква у в. Тонава Слабодка [w:] Памяць: гісторыка-дакументальная Стаўбцоусккага района, рэд. І.П. Пашкоў і інш., Мінск 2004, s. 752. 
kamykami u Jezusa. Nad ich głowami znajdują się korony, z prawej i lewej strony umieszczono czternaście metalowych wotów. Liczne otwory na płótnie wskazują, że było ich znacznie więcej. Tło i szyję Matki Bożej zdobią łańcuszki i sznury korali, w tym również współczesne, świadczące o wciąż trwającym kulcie ikony. U dołu obrazu widnieje data jego powstania, zapisana cyrylicą (1565). Tę samą datę podano w pochodzącej z lat 1860-1870 kronice (latopisie) cerkwi tonowo-słobodzkiej. Datę umieszczono w tekście obok informacji, że w cerkwi znajduje się „местночтимая чудотворная икона Пресвятой Богородицы, писанная на холсте" (lokalnie czczona ikona Bogurodzicy namalowana na płótnie) ${ }^{55}$. Niewykluczone jednak, że dopisano ją w kronice później, ponieważ w kolorze użytego atramentu i stylu pisma są wyraźnie widoczne różnice. Według latopisu na początku lat trzydziestych XVIII w. cerkiew, w której znajdowała się ikona, spłonęła wraz z wyposażeniem. Ikonę ocaliła z płomieni jakaś nadprzyrodzona siła, która przeniosła ją na drzewo klonowe. W miejscu drzewa wybudowano w 1736 r. nową cerkiew ${ }^{56}$.

W końcu XIX w. powstała legenda, według której mieszkaniec wioski Słobodka poił konia w pobliskiej rzece Sule i zauważył, że zwierzę uderza kopytem w wodę, chcąc usunąć jakąs przeszkodę. Mężczyzna wyciągnął z wody deskę, na której widniał wizerunek Bogurodzicy z Dzieciątkiem. Według legendy na policzku Marii pozostał ślad po końskim kopycie ${ }^{57}$. Ikona pozostaje w kulcie Cerkwi prawosławnej do dzisiaj. W czasach współczesnych ustalono dzień kultu Matki Bożej namalowanej na opisanym obrazie - jest to 21 lipca według nowego stylu, dzień, w którym rosyjska Cerkiew prawosławna oddaje cześć Bogurodzicy Kazańskiej.

Drugim przykładem jest obraz Matki Bożej Wniebowziętej (Niepokalanego Poczęcia?), znanej pod nazwą Matki Bożej Krzywickiej (il. 5). Obraz znajduje się we wsi Bielica i jest otoczony czcią zarówno przez katolików, jak i prawosławnych. Oryginał, który pochodzi z kaplicy w Krzywiczach (zniszczonej po 1939 r.), wisi w kościele św. Jerzego w Bielicy ${ }^{58}$. Aby prawosławni mogli odwiedzać czczony przez nich wizerunek Matki Bożej, parafianie Stefan i Antonina Karabacz ufundowali w 1935 r. kopię, którą umieszczono w cerkwi bielickiej. Obraz do dzisiaj pozostaje w kulcie Cerkwi prawosławnej, chociaż przedstawia Matkę Bożą w typie opartym na zasadach Kościoła katolickiego. Wśród miejscowej ludności wyznania prawosławnego zachowała się legenda o pochodzeniu obrazu, spisana przeze mnie w 2008 r. w oparciu o relację Aleksandra Korolczuka. Według legendy ikona objawiła się na gruszy kilka wieków temu i w miejscu objawienia zbudowano kaplicę. Z nakazu Bogurodzicy w kaplicy nie wolno było brać ślubu ani

НИАБ, ф. 886, оп. 1, д. 1, f. 1.

56 Ibidem, f. 1-1v.

57 Анатоль. Валахановіч, Благадатны шлях: нататкі удзельніка хрэснага ходу, „Минские епархиальные ведомости" 1997, nr 3, s. 60.

58 Anna Korzeniowska, Katarzyna Mączewska, Kościół parafialny pw. św. Jerzego w Bielicy [w:] Kościoły i klasztory rzymskokatolickie dawnego województwa wileńskiego, red. naukowa Maria Kałamajska-Saeed, t. 2, Kraków 2005, s. 45. 


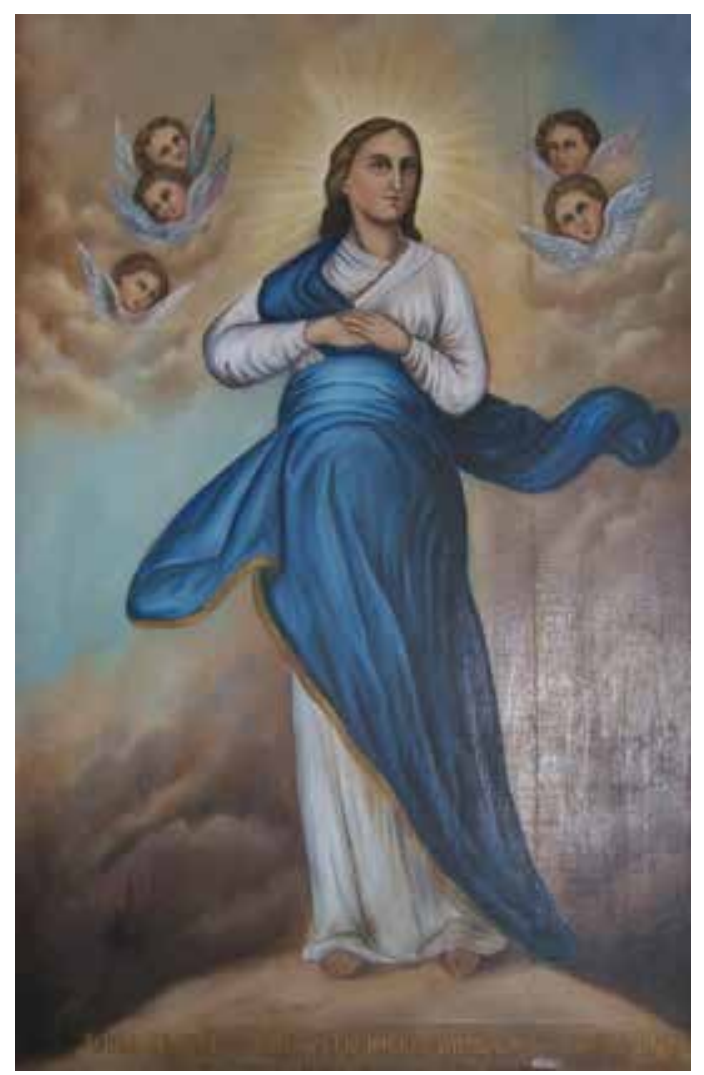

Il. 5. Obraz Matki Bożej Krywickiej, cerkiew w Bielicy, fot. Volha Barysenka, 2008 przyjmować chrztu. Kiedy jeden z ziemian złamał zakaz i zawarł w świątyni związek małżeński, kaplica wraz z cudownym obrazem spłonęła od uderzenia pioruna. Obraz został namalowany ponownie ,z pamięci” i umieszczony w odbudowanej kaplicy, skąd trafił do kościoła bielickiego.

W dokumentach opisano jeszcze inne przypadki adaptacji sakralnych wizerunków zachodnich do kultu prawosławnego. Obrazy te się nie zachowały, trudno więc powiedzieć cokolwiek pewnego o ich ikonografii. Można się tylko odwołać do sporządzonego przez autorów dokumentów/publikacji bardzo krótkiego opisu dzieła i jego charakterystyki jako nietypowej dla prawosławia. Przykładem może być wizerunek Chrystusa, określony w opisie biskupa połockiego i witebskiego (sporządzonym po wizycie w cerkwi we wsi Sołoniewicze w 1891 r.) jako „рельефное изображение Спасителя в терновом венце" (reliefowy obraz Zbawiciela w koronie cierniowej). Wizerunek znajdował się w kaplicy obok cerkwi. Był to niewątpliwie typ krucyfiksu albo Chrystus Frasobliwy, brakuje jednak szczegółowego opisu. Autor charakterystyki stwierdził, że wizerunek, chociaż zrobiony nie do końca w duchu Cerkwi prawosławnej („Хотя это изображение сделано не совсем в духе Православной Церкви”), роzostawiono, dlatego że czciła go zarówno ludność prawosławna, jak i katolicka. Katolicy oglądali obraz Chrystusa, wstępując do cerkwi w drodze do kościoła w Zahaciu, modlili się i rzucali skromne datki do skarbonki. W wyniku tego cerkiew sołoniewicka miała największy dochód, szczególnie w dzień katolickiego święta Trójcy Świętej („самый большой доход бывает здесь именно от католиков, и именно в день празднования в Загатском костеле Святой Троицы”) $)^{59}$.

Kościelne cudowne wizerunki przedstawiające Matkę Bożą z Dzieciątkiem lub Jezusa Chrystusa ze świętymi Kościoła katolickiego zostawiano również w cerkwiach prawosławnych, które przebudowano z kościołów katolickich. Tak

59 НИАБ, ф. 886 , оп. 1, д. 1, f. 461-461v. 
było w przypadku cudownego obrazu Najświętszej Panny z Krywoszyna (il. 6). Na przedstawieniu przed Matką Bożą trzymającą Jezusa klęczą założyciele zakonu jezuitów - Ignacy Loyola (po prawej stronie) i Franciszek Ksawery (po lewej stronie). Alaksiej Chadyka sugerował, że obraz, czczony już jako cudowny, mógł powstać wcześniej. A przeniesiono go do Krywoszyna w roku 1670, kiedy to lokalizację zmieniało też centrum misyjne jezuitów w Lipsku ${ }^{60}$.

Na oddzielną uwagę zasługują obrazy świętych katolickich, które rozpowszechniły się w Cerkwi unickiej - a mianowicie wizerunki św. Antoniego Padewskiego, teologa franciszkańskiego, który był najbardziej popularnym świętym katolickim w Cerkwi unickiej ${ }^{61}$. Cerkiew prawosławna nie uznaje kultu św. Antoniego, obrazy miały być usunięte z przekształconych świątyń. Jednak na Wołyniu, w pounickiej cerkwi we wsi Podlesce, został cudowny wizerunek katolickiego świętego trzymającego Dzieciątko Jezus na rękach. Święty był czczony przez miejscowych chłopów jako obrońca tych,

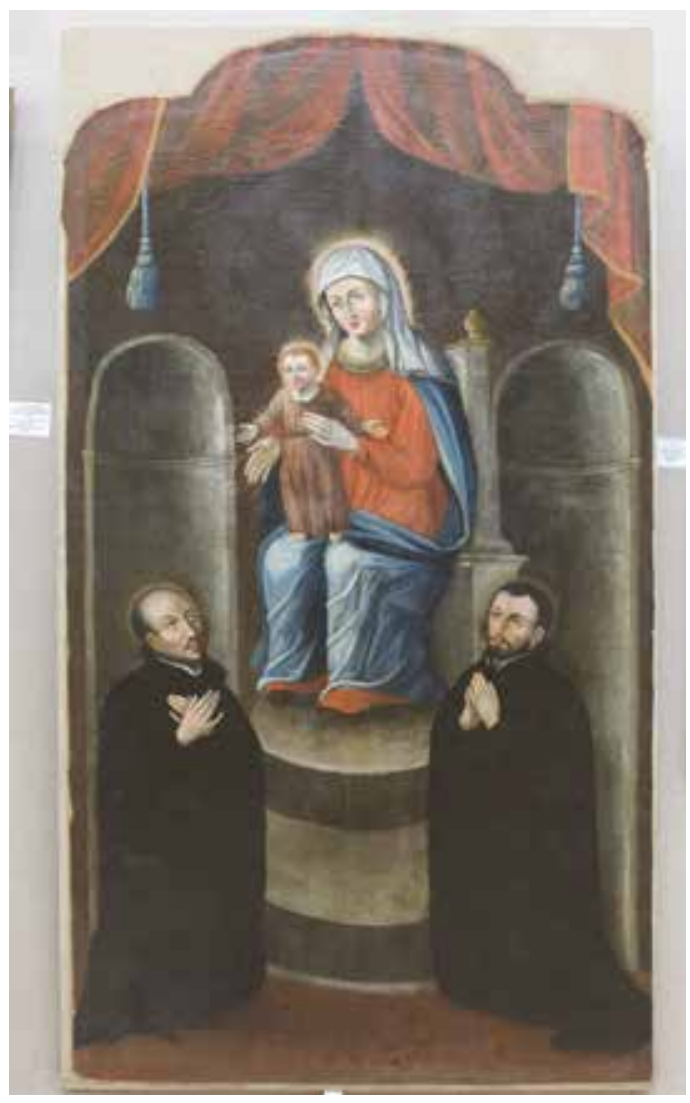

Il. 6. Obraz Matki Bożej z Krywoszyna, fot. Włodzimier Sutiagin, 2013 którzy ucierpieli z powodu kradzieży, zwłaszcza koni. Do cerkwi przychodzili chłopi z miejscowości położonych nawet o 150 wiorst od Podlesców i przynosili figurki koni zrobione z wosku. W 1864 r. arcybiskup wołyński Antoni, odwiedzając cerkwie wołyńskie, zauważył obraz w szczycie sanktuarium („na miejscu górnym”) i zarządził jego usunięcie. Wówczas jeden $\mathrm{z}$ chłopów odpowiedział, że Antoni może nie jest świętym, jednak trzyma Jezusa Chrystusa, a Jezus Chrystus to nie tylko święty, ale i Bóg, tak więc być może to sam Jezus Chrystus czyni cuda. I poprosił arcybiskupa, żeby obraz pozostał w cerkwi („може Антоний и не святый, того мы не знаем, но у него на руках Иисус Христос..., а Иисус Христос то не тылько Святый, а еще и Бог, то мы тэе добре знаем, то може и чуда творыть Сам

60 Хадыка Аляксей Юр'евіч, Да атрыбуцыььі «Маці Боскай» з Крывошына [w:] Помнікі мастацкай культуры Беларусі, Мінск 1989, s. 41.

61 Mirosław Piotr Kruk, Złoty Ołtarz wonnego kadzenia albo ikona Bramy Niebios (?) w otoczeniu świętych trzech obrzadków - apoteoza Matki Bożej, apoteoza Unii kościelnej, apoteoza dawnej Rzeczypospolitej..., s. 129-130. 
Volha Иисус Христос, сидящий на руках у Антония. Нехай той образ, Ваше Barysenka Преосвящество, таки там буде") ${ }^{62}$. Warto zaznaczyć, że po dołączeniu cerkwi do Cerkwi prawosławnej katolicy kilkakrotnie zwracali się do prawosławnego konsystorza duchownego z prośbą o oddanie obrazu katolikom, jednak prośba ta była odrzucana, ponieważ obraz czcili też nawróceni prawosławni ${ }^{63}$. Natomiast w cerkwi unickiej w Mołczadzi w powiecie słonimskim otoczoną kultem rzeźbę św. Antoniego Padewskiego zamieniono w 1865 r. na ikonę czcigodnego Antoniego, a mimo to jeszcze w roku 1894 wciąż żywy był tam kult rzeźby, której fragmenty można było dostrzec przez okienko w krypcie cerkiewnej. Miejscowa ludność, odbywając pielgrzymki do cerkwi, wrzucała przez to okno datki ${ }^{64}$.

Przypadki rywalizacji między katolikami i prawosławnymi o ten lub inny cudowny wizerunek były częste. Jeśli kult obrazu był mocno zakorzeniony w środowisku, które zgodnie z polityką caratu podlegało rusyfikacji, obraz pozostawał najczęściej w posiadaniu Cerkwi. Chociaż znane są przypadki, kiedy wbrew dawnemu unickiemu pochodzeniu i obecności kultu ikony w środowisku wyznawców prawosławia wizerunek pozostawał w posiadaniu unitów (do czasu likwidacji unii) lub katolików. Przykładem jest obraz Matki Bożej z kaplicy na Bramie Słuckiej w Nieświeżu. W końcu XIX w. duchowny prawosławny zabiegał o jej przeniesienie do cerkwi, jednak obraz pozostał w kaplicy i na przełomie XIX i XX w. opiekowali się nim wyłącznie katolicy ${ }^{65}$.

A zatem w wielu przypadkach o wprowadzeniu dziel sztuki sakralnej o pochodzeniu zachodniochrześcijańskim do kultu Cerkwi prawosławnej decydowało w tzw. guberniach zachodnich istnienie lub nieistnienie odrębnego kultu obrazu wśród ludności, a zwłaszcza traktowanie go jako cudownego. Kult cudownych wizerunków miał charakter ponadwyznaniowy, chrześcijanie nawiedzali je niezależnie od konfesyjnej przynależności świątyni. Służyło to najczęściej dwóm celom - określonym w dokumentach - nawracaniu unitów i katolików na prawosławie, a wraz z tym wzmacnianiu wsparcia polityki imperialistycznej, oraz - w niektórych przypadkach - zwiększaniu dochodów z ofiar składanych przez wiernych. Przekazanie takich wizerunków Kościołowi katolickiemu prowadziłoby do wzmocnienia katolicyzmu i wsparcia idei o odbudowaniu dawnej Rzeczypospolitej. Usuwanie lub znacząca zmiana oblicza takich wizerunków mogła doprowadzić do konfrontacji z parafianami i utrudnić duszpasterstwo, co też było niepożądane.

62 Николай Иванович Теодорович, Историко-статистическое описание иерквей и приходов Вольнской епархии. Том III. Уездь Кременеикий и Заславский, Почаев 1893, s. 465.

63 Ibidem, 466-468.

64 Николай Дмитриевич Извеков, Исторический очерк состояния Православной Церкви в Литовской епархии за время 1839-1889, s. 437-438.

65 Ольга Владимировна Борисенко, К истории чудотворной иконь Богоматери из Слуикой брамы в Несвиже и вопрос о её конфессиональной принадлежности (XVIIXVIII вв.) [w:] Беларуская даўніна, рэд. Юрый Мікалаевіч, vol. 3, Мікульскі 2016, s. $106-113$. 
Należało zatem uzasadnić funkcjonowanie tych wizerunków w Cerkwi poprzez rozpowszechnianie legend o ich pierwotnym prawosławnym pochodzeniu. Można stwierdzić, że działalność ta przynosiła pożądane efekty - wizerunki, Polityka rosyjskiej Cerkwi... które przetrwały nieszczęścia XX w., pozostają wciąż w kulcie cerkiewnym wraz z towarzyszącymi im legendami o prawosławnym pochodzeniu, powtarzanymi także w publikacjach o charakterze naukowym.

\section{Bibliografia}

Ciołka Dariusz, Latynizacja Kościoła unickiego w Rzeczypospolitej po synodzie zamojskim, Białystok 2014.

Jaroszewicz Aleksander, Przebudowy kościołów katolickich na cerkwie prawosławne na Białorusi po powstaniu styczniowym (w świetle materiałów archiwalnych) [w:] Kultura i polityka. Wplyw polityki rusyfikacyjnej na kulturę zachodnich rubieży Imperium Rosyjskiego (1772-1915), red. Dariusz Konstantynów, Piotr Paszkiewicz, Warszawa 1994.

Jurkowski Gabryel, Morze litości y łaski Bożey przepaściste z Rożanego-Stoku wylane..., Wilno 1762.

Kałamajska-Saeed Maria, Ostra Brama w Wilnie, Warszawa 1990.

Korzeniowska Anna, Mączewska Katarzyna, Kościót parafialny pw. św. Jerzego w Bielicy [w:] Kościoly i klasztory rzymskokatolickie dawnego wojewodztwa wileńskiego, red. Maria Kałamajska-Saeed, t. 2, Kraków 2008, s. 45.

Kruk Mirosław Piotr, Złoty Ołtarz wonnego kadzenia albo ikona Bramy Niebios (?) w otoczeniu świętych trzech obrządków - apoteoza Matki Bożej, apoteoza Unii kościelnej, apoteoza dawnej Rzeczypospolitej [w:] Sztuka cerkiewna Rzeczypospolitej i krajów sasiednich. Materialy dyskusyjne, red. Dominika Maria Macios, Magdalena Anna Piecyk, Maria Tsymbalista, Ostrawa-Warszawa 2020, s. 120-121.

Opacki Zbigniew, Likwidacja Unii kościelnej na „Ziemiach zabranych” w 1839 roku [w:] Polska - Ukraina. 1000 lat sąsiedztwa t. 2, Studia z dziejów chrześcijaństwa na pograniczu kulturowym i etnicznym, red. Stanisław Stępień, Przemyśl 1994, s. 119-130.

Sapieha Jan Fryderyk, Monumenta Antiquitatum Marianum In [sic!] Imagine Vetustissima, vulgo Gregoriana, a S. Augustino Romano depicta Integerrima Virginis Deiparce de Gvadelupe Codnensis, Agusta Origine, [et] devoto Cultu Fidelium Gloriosissime Laureatis Martyrum, Variorumq[ue] Celitum; Exuvijs Circumdatoe, pars 1, Warszawa 1721.

Sygowski Paweł, Rosyjskie Muzeum Cerkiewno-Archeologiczne w Chetmie (1882-1915) jego powstanie i zbiory sztuki religijnej (malarstwo, rzeźba), „Rocznik Chełmski” 2013, t. 17, s. 85-118.

Waclaw z Sułgostowa (Nowakowski), O cudownych obrazach w Polsce Przenajświętszej Matki Bożej, Kraków 1902.

Wiadomość historyczna o cudownym obrazie N. Panny Maryi w Bialyniczach [w:] Posłaniec Bractwa N. P. Maryi Królowej Korony Polskiej, Kraków 1899, s. 10-62. 
Volha А.В.Б., Икона Бельничской Божией Матери... [w:] Виленский календарь на 1887 Barysenka год, Вильна 1886, s. 107.

Акт благочиннической конгрегачии (собора) Брагинского благочиния, Минской губернии, Речицкого уезда, „Литовские епархиальные ведомости” 1864, nr 14, s. 515-526.

Археографический сборник документов, относящихся к истории Северо-Западной Руси, издаваемьй при Управлении Виленского учебного округа, t. 9, Вильна 1870.

Батюшков Помпей Николаевич, Белоруссия и Литва. Исторические судьбы Северо-Западного края, Минск 2004 (переиздание).

Беларускі іканастас. Творы іканапісу і драўлянай пластыкі канияа XVII-nач. XIX cm. Буклет да выстаўкі, складальнік Алена Карпенка, Мінск 2015.

Борисенко Ольга Владимировна, Белорусские чудотворные иконы Богоматери, связанные со святым Димитрием Ростовским (Туптало) [w:] Волинська ікона: дослідження та реставрація. Науковий збірник. Випуск 28. Матеріали XXVIII міжнародної наукової конференції, м. Луцьк, 21-22 жовтня 2021 року, Упоряд. Т. Єлісєєва, Є. Ковальчук, Луцьк, 2021, s. 52-61.

Борисенко Ольга Владимировна, К истории чудотворной иконы Богоматери из Слуикой брамы в Несвиже и вопрос о её конфессиональной принадлежности (XVII-XVIII вв.) [w:] Беларуская даўніна, рэд. Юрый Мікалаевіч Мікульскі, 2016, vol. 3, s. 106-113.

Валахановіч Анатоль, Благадатны шлях: нататкі ўдзельніка хрэснага ходу, „Минские епархиальные ведомости" 1997, nr 3, s. 60-64.

Долбилов Михаил, Русский край, чужая вера: этноконфессиональная политика империи в Литве и Белоруссии при Александре II, Москва 2010.

Еленов Сидор, Осввящение иерквей: Освящение Красностокской церкви, „Литовские епархиальные ведомости" 1867, nr 22, s. 950-959.

Епархиальная хроника, „Минские епархиальные ведомости” 1907, nr 18, s. 364-365.

(Жудро) Василий, иеромонах, Исторические материаль из дел Могилевской духовной консистории о передаче в православное духовное ведомство Бельничского римско-католического костела с находящеюся в нем чудотворной иконой Божией матери Бельничский Рождество-Богородицкий монастырь: В 2 ч. Кн. 2-3, б.в.д.

Из бумаг графа М.Н. Муравьева. С предисловием графа С.Д. Шеремета, Санкт-Петербург 1898.

Извеков Николай Дмитриевич, Исторический очерк состояния Православной Церкви в Литовской епархии за время 1839-1889, Москва 1899, s. 389-393.

Кривонос Феодор, Свято-Аннинская церковь в Столбиах, „Минские епархиальные ведомости" 2004, nr 3, s. 59-63.

Куцевич Август, священник, Крестный ход из. Волковыска в м. Зельву с перенесением иконы Иверской Божией Матери, „Литовские епархиальные ведомости” 1867 , nr 2, s. 887-897.

„Минские епархиальные ведомости” 1907, nr 18, s. 364-366.

Описание иерквей и приходов Минской епархии, составленное по обиииально затребованным от причтов сведениям. Ч. I: Минский уезд (Приложение к Минским епархиальным ведомостям за 1878 г.), Минск 1878. 
Освящение Верховицкого римско-католического костела в православную иерковь Polityka 1867 г 24 июля, и историческая заметка по поводу этого торжества, „Литовские епархиальные ведомости” 1867, nr 23, s. 1021-1033.

Пашкевич Михаил Михайлович, Чудотворная икона Богородицы в Борунах. С краткими сведениями о монастьре и училище, Вильна 1907.

Проволович Иоанн, Из путешествия Его Преосвященства, Преосвященнейшего Александра, епископа Минского и Бобруйского, по Епархии в 1873 году, „Минские епархиальные ведомости” 1873, nr 24, s. 563-594.

Семеняко Николай, Красностокская чудотворная икона Божией Матери, Гродно 1901.

Сказание об истории и чудесах чудотворной иконы Божией Матери Юровичской Милосердной, Мозырь 2010.

Соболевский Иван Викентьевич, Сказание об Остробрамской иконе Божией Матери, находящейся в Вильне, изд. 6-е, Вильна 1907.

Теодорович Николай Иванович, Историко-статистическое описание иерквей и приходов Вольнской епархии. Том III. Уезды Кременеикий и Заславский, Почаев 1893.

Флікоп-Світа Галіна Аляксандраўна, Барацьба за выяву Бога: лёс алтарных кариін иарквы у вёсиьы Шиорсы Навагрудскага павета пасля скасавання Уніi, „Архіварыус" 2017, вып. 15, s. 294-304.

Ченстоховская чудотворная икона Богородицы в Ченстоховском Ясногорском монастыре и Церковь во имя святых равноапостольных просветителей славян Кирилла и Мефодия в городе Ченстохове с точною копией Ченстоховской святой иконы Богородиць, Вильна 1881.

Юр'евіч Аляксей, Да атрыьуциьі «Маці Боскай» з Крьвошььна [w:] Помнікі мастаикай культуры Беларусі, Мінск 1989, s. 40-44.

Ярашэвіч Аляксандр Адамавіч, Маці Божая Снежная ў Беларусі, Мінск 2003.

Ярашэвіч Аляксандр Адамавіч, Царква ў в. Тонава Слабодка [w:] Памяць: гісторыка-дакументальная Стаўбиоўскага района, рэд. І.П. Пашкоў і інш., Мінск 2004, s. 751-752.

\section{Policy of the Russian Orthodox Church Towards Miraculous Images of Western- -Christian Origin in the Eastern Territories of the Former Polish-Lithuanian Commonwealth in the $19^{\text {th }}$ Century}

Due to the liquidation of the Union in 1839 and the transfer of Catholic churches to the Orthodox Church after the rebellions of 1830-1831 and 1863-1864 in the territories of the former Polish-Lithuanian Commonwealth which were incorporated into the Russian Empire, a great deal of sacred art pieces of western-Christian art became property of the Orthodox Church. As per directions of the Church authorities, the images of Jesus Christ, Our Lady and the Saints of the Undivided Church could remain in Orthodox churches, while those of Catholic and Greek-Catholic Saints were to be given back to Catholics. The images that were left in Orthodox churches were to be changed to meet the Orthodox rules. That usually meant addition of an inscription or repainting of the image partially or fully. 
Volha The situation was different in relation to miraculous images. After being transferred Barysenka to the Orthodox churches they remained unchanged, even in the cases when their iconography was unacceptable for the Orthodox Church or when they represented Catholic Saints, such as Ignatius Loyola or Anthony of Padua. This was related to the effect miraculous images had on local communities. The cult of miraculous images was above-confessional; believers of different Christian confessions went on pilgrimages to them. Leaving these images as is they were aimed at converting Catholics to Orthodoxy to strengthen the position of the Russian Empire on the land of the former Polish-Lithuanian Commonwealth. To justify the functioning of western-Christian images in the Orthodox Church, both new legends were developed stating the images had Orthodox origins and were taken by Catholics, and attempts of theological rationale were made. These activities were successful: the images that survived through the disasters of the $20^{\text {th }}$ century are still in the cult of the Orthodox Church along with the legends of their Orthodox origin developed in the $19^{\text {th }}$ century. 